\title{
PENETAPAN KADAR FLUORIDA PADA SAMPEL PASTA GIGI MENGGUNAKAN METODE SPEKTROFOTOMETRI SINAR TAMPAK
}

\section{DETERMINATION OF FLUORIDE LEVELS ON TOOTHPASTE SAMPLES USING THE VISIBLE SPECTROPHOTOMETRIC METHOD}

\author{
Ivan Andriansyah, Ikhsan Permana \\ Sekolah Tinggi Farmasi Bandung \\ Jl. Soekarno Hatta no. 754, Cibiru Bandung \\ Email: ivan.andriansyah@stfb.ac.id
}

\begin{abstract}
ABSTRAK
Fluorida merupakan salah satu komponen pasta gigi yang dapat menghambat pertumbuhan bakteri dalam rongga mulut, namun asupan fluorida yang berlebihan dalam jangka waktu yang lama dapat menyebabkan fluorosis pada gigi dan tulang. Penelitian dilakukan untuk mengetahui kadar senyawa fluorida dengan menggunakan pereaksi SPADNS - Asam Zirkonium dengan beberapa sampel varian yang ada di pasaran. Penelitian dilakukan dengan mendestruksi sampel dengan pelarut $\mathrm{HNO}_{3}$ dan beberapa tetes $\mathrm{H}_{2} \mathrm{O}_{2}$ sehingga didapat larutan bening. Kemudian sampel ditambah pereaksi Sodium 2-(Para-sulfophenylazo) - 1,8dihydroxy -3,6-napthalene disulfonate (SPADNS) - asam zirkonil dan diukur dengan spektrofotometri sinar tampak. Diperoleh nilai panjang gelombang maksimum natrium fluorida $585 \mathrm{~nm}$. Metode ini memiliki nilai akurasi dan presisi yang baik. Beberapa sampel menunjukkan bahwa kadar fluorida bervariasi antara 527,326 - 729,306 $\mu \mathrm{g} / \mathrm{ml}$. Konsentrasi fluorida pada beberapa sampel pasta gigi (anak, hotel dan media online) masih berada di bawah rentang persyaratan dalam Peraturan Kepala Badan Pengawasan Obat dan Makanan Republik Indonesia No. HK. 03.1.23.08.11.07517 Tahun 2011 tentang Persyaratan Teknis Bahan Kosmetika yang telah menetapkan bahwa jumlah senyawa fluorida yang boleh terkandung dalam pasta gigi tidak boleh lebih dari $0,15 \%$ atau $1500 \mu \mathrm{g} / \mathrm{ml}$ dihitung dari kadar total F (fluorida).
\end{abstract}

Kata kunci : Fluorida, pasta gigi, spektrofotometri, sinar tampak

\begin{abstract}
Fluoride is one component of toothpaste that can inhibit bacterial growth in the oral cavity, but excessive fluoride intake over long periods of time can cause fluorosis in the teeth and bones. The study was conducted to determine the level of fluoride compound by using SPADNS-Zirconium Acid with some variant samples in the market. The study was conducted by destruction of the sample with $\mathrm{HNO} 3$ and a few drops of $\mathrm{H} 2 \mathrm{O} 2$ to obtained clear solution. Then sample was added reagent Sodium 2-(Para-sulfophenylazo) - 1,8dihydroxy-3,6-napthalene disulfonate (SPADNS) - zirconil acid and measured by visible spectrophotometry. Maximum wavelength value sodium fluorida is $585 \mathrm{~nm}$. This method has a good value of accuracy and precision. Some samples showed that fluoride levels are varied
\end{abstract}


between $527,326-729,306 \mu \mathrm{g} / \mathrm{ml}$. Concentration of fluoride in some samples of toothpaste (children, hotels and online media) is still below the requirements range in regulation the Head of the National Agency of Drug and Food Control, the Republic of Indonesia No. HK. 03.1.23.08.11.07517 of 2011 on the Technical Requirements of Cosmetics Materials have determined that the amount of fluoride compounds contained in toothpaste shall not exceed $0.15 \%$ or $1500 \mu \mathrm{g} / \mathrm{ml}$ calculated from total $\mathrm{F}$ (fluoride) content.

Keywords: Fluoride, toothpaste, Spectroscopy, Visible

\section{PENDAHULUAN}

Sejak dulu sampai sekarang telah menjadi rutinitas bagi manusia untuk selalu tampil menarik. Keinginan ini dapat terwujud dengan menggunakan berbagai macam produk kosmetik. Salah satunya adalah pasta gigi, pasta gigi merupakan kosmetik yang sering di gunakan oleh balita, anak-anak dan dewasa.

Pada umumnya, pasta gigi mengandung chemotherapeutic agent yang dapat meningkatkan kesehatan rongga mulut karena dapat memicu terbentuknya zat penghambat terjadinya pembentukan plak dan kolonisasi bakteri (Adwan dkk., 2012). Pasta gigi juga memiliki kandungan penting lain yaitu zat anti bakterial. Zat anti bakterial dalam pasta gigi pada umumnya adalah flourida yang dapat menghambat metabolisme bakteri, khususnya proses glikolisis, walaupun dalam kondisi yang asam. Flourida juga dapat berperan dalam proses remineralisasi enamel. Oleh karena itu, flourida dapat membantu dalam proses pencegahan pertumbuhan bakteri karsiogenik dan bakteri yang tahan dalam keaadaan asam seperti Streptococcus mutans (Philip dan Michael, 2009).

Kandungan flourida dalam pasta gigi biasanya berbentuk natrium flourida $(\mathrm{NaF})$, stanium flourida (SnF) ataupun dalam bentuk natrium monofluorofosfat (Haveles, 2011). Konsentrasi maksimum flourida pada pasta gigi berkisar sekitar 1000-1500 $\mu \mathrm{g} / \mathrm{ml}$ (Haris dan Garcia, 2004).

Penggunaan pasta gigi berfluorida ini memiliki resiko, jika penggunaan senyawa fluorida yang berlebihan ke dalam tubuh maka akan menyebabkan fluorosis gigi (Fawel dkk., 2006). Fluorida dengan dosis yang sama dapat menyebabkan tingkat fluorosis gigi yang berbeda. Keparahan fluorosis gigi tergantung pada waktu dan lamanya keterpaparan fluorida, respon individu, berat badan, tingkat aktifitas fisik, faktor gizi, dan pertumbuhan tulang (Malau I, 2009).

Penetapan kadar zat aktif merupakan persyaratan yang harus dipenuhi untuk menjamin kualitas sediaan kosmetik. Sediaan kosmetik yang baik akan menunjang efek yang diharapkan tanpa memberikan efek samping yang dapat merugikan. Persyaratan yang telah ditentukan oleh Peraturan Kepala BPOM Republik Indonesia Nomer HK.03.1.23.08.11.07517 Tahun 2011 tentang persyaratan teknis kosmetik. Penetapan kadar Fluorida dapat di analisis atau dapat tentukan kadarnya secara spekrofotometri sinar tampak (Vis) dengan menggunakan pereaksi Sodium 2-(para-sulfophenylazo)1,8-dihydroxy-3,6naphtalen disulfonat (SPADNS)-Asam zirkonil (water analiysis handbook, 2nd, 1992).

Melihat berbagai penelitian bahwa pasta gigi yang mengandung fluorida yang melampaui batasan yang telah di tetapkan dapat menyebabkan fluorosis pada gigi (Fawel dkk., 2006) dan dari penelitian yang dilakukan tentang analisis klorida dan florida pada air bersih (Sellyni.,2013). Maka saya ingin melakukan penelitian mengenai penetapan kadar fluorida pada pasta gigi hotel, pasta gigi anak dan yang beredar di media online.

Untuk menentukan kadar senyawa fluorida dengan melakukan analisis secara spektrofotometri dengan menggunakan pereaksi Sodium 2-(para-sulfophenylazo)1,8dihydroxy-3,6-naphtalen disulfonat (SPADNS)-Asam zirkonil dengan beberapa sampel varian yang beredar dipasaran 


\section{METODE PENELITIAN}

Alat dan Bahan

\section{Alat}

Alat-alat yang digunakan dalam penelitian ini antara lain spektofotometri sinar tampak, alat-alat gelas.

\section{Bahan}

Natrium fluorida (Merck, pro analisis), SPADNS sodium 2-(parasulfofenylazo 1,8dihidroksi - 3,6-naftalen disulfonat) Zirkonil klorida oktahidrat $\left(\mathrm{ZrOC}_{12}-8 \mathrm{H}_{2} \mathrm{O}\right)$, Asam klorida $(\mathrm{HCl})$ pekat (Merck, pro analisis), Asam nitrit $\left(\mathrm{HNO}_{3}\right)$ pekat (Merck, pro analisis), Hidrogen peroksida $\left(\mathrm{H}_{2} \mathrm{O}_{2}\right)$ (Merck, pro analisis), Aquabides dan tiga varian sampel pasta (hotel, anak dan yang beredar di media online).

\section{Jalannya Penelitian}

Pada tahap awal penelitian dilakukan pengumpulan sampel pasta gigi yang diperoleh dari hotel, pasta gigi anak dan online. Selanjutnya sampel pasta gigi dilakukan preparasi sampel dengan menggunakan 3 perbandingan yaitu dengan Air, $\mathrm{HCl}$ dan $\mathrm{HNO}_{3}$. Kemudian pembuatan beberapa larutan pereaksi. Diantaranya pembuatan larutan SPADNS (sodium 2parasulfofenylazo 1,8-dihidroksi- 3,6-naftalen disulfonat) dan pembuatan larutan asam zirkonil. Setelah itu, dilakukan optimasi kondisi analisis natrium fluorida dengan pereaksi SPADNS-asam zirkonil secara spektrofotometri sinar tampak yang meliputi penentuan panjang gelombang maksimum dan penentuan kestabilan serapan warna kompleks hasil reaksi natrium fluorida dengan pereaksi SPADNS-Asam zirkonil. Berikutnya, melakukan verifikasi metode analisis natrium fluorida secara spektrofotometri sinar tampak yang meliputi uji linearitas, penentuan batas deteksi (LOD) dan batas kuantifikasi (LOQ), uji keseksamaan dan uji kecermatan pada sampel pasta gigi dengan menggunakan metode penambahan baku.

\section{Analisis Data}

$$
\begin{aligned}
L O D=3,3 \frac{S D}{S} \text { dan } L O Q & =10 \frac{S D}{S} \\
\text { Dimana: } \quad \text { LOD } & =\text { Batas Diteksi } \\
\text { LOQ } & =\text { Batas Quantifikasi } \\
\text { SD } & =\text { Standar Deviasi } \\
\text { S } & =\text { Respon Kemiringan (Slope) }
\end{aligned}
$$

\section{HASIL DAN PEMBAHASAN}

\section{Pembuatan Larutan Baku fluorida dan Larutan Standar Fluorida}

Larutan induk dengan konsentrasi sebesar $100 \mu \mathrm{g} / \mathrm{ml}$ dibuat dengan cara melarutkan $\mathrm{NaF}$ sebanyak $10 \mathrm{mg}$ dengan $100 \mathrm{ml}$ aquabides. kemudian di encerkan kembali dari larutan induk sehingga menghasilkan larutan standar $10 \mu \mathrm{g} / \mathrm{ml}$. Larutan standar tersebut selanjutnya dibuat kedalam 6 seri pengenceran $1 ; 1,5 ; 2 ; 2,5 ; 3$ dan 3,5. 


\section{Optimasi Kondisi Analisis Fluorida dengan Pereaksi SPANDS-Asam Zirkonil secara Spektrofotometri Sinar Tampak}

\section{Penentuan Panjang Gelombang}

Pada penelitian ini pengukuran dilakukan dengan menggunakan alat spektrofotometri sinar tampak pada panjang gelombang maksimum dari 400-800 nm. Spektrum serapan untuk memperoleh panjang gelombang maksimum dibuat larutan standar natrium fluorida dengan konsentrasi $1 ; 1,5$ dan $2 \mu \mathrm{g} / \mathrm{ml}$ yang dicampurkan dengan pereaksi SPANDS-Asam Zirkonil dan panjang gelombang 400-800 $\mathrm{nm}$ kemudian diperoleh hasil rata-rata dalam percobaan ini yaitu $585 \mathrm{~nm}$. Pada peneltian ini telah terjadinya pergeseran panjang gelombang ke arah yang lebih besar. Peristiwa penambahan panjang gelombang dari yang seharusnya disebut bathokromik, bathokromik ini dapat terjadi karena adanya perubahan $\mathrm{pH}$ dari larutan pereaksi (Gandjar \& Rohman, 2007).

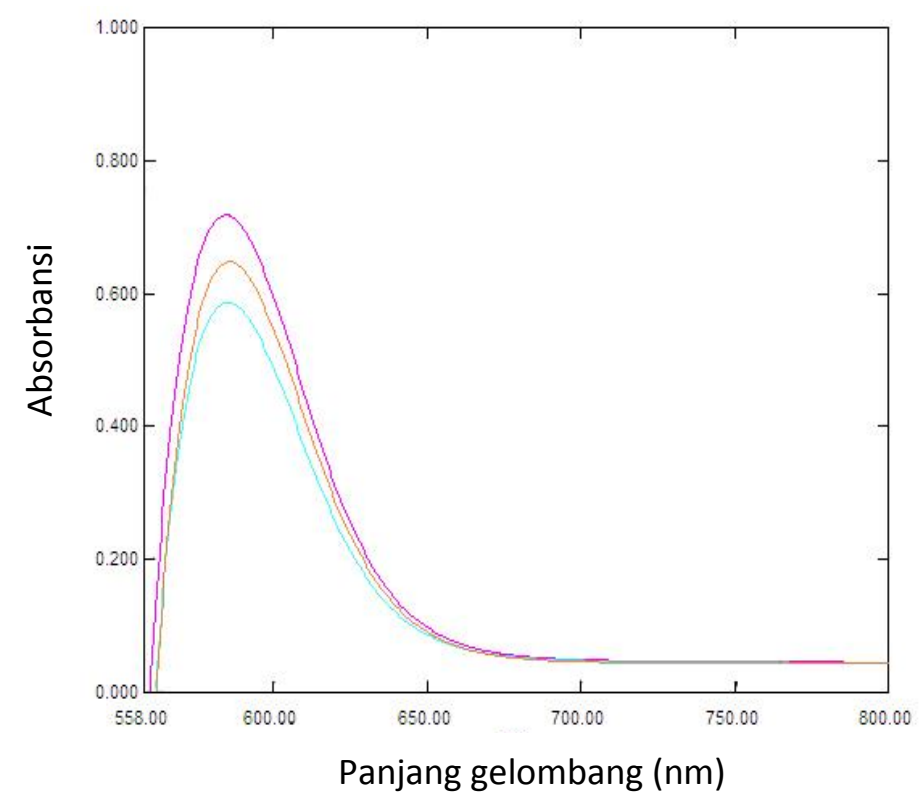

Gambar 1. Pengukuran panjang gelombang maksimum pereaksi SPADNS-Asam Zirkonium

\section{Penentuan Kestabilan Serapan Warna Kompleks Hasil Reaksi Fluorida Dengan Pereaksi SPANDS-Asam Zirkonil}

Untuk memenuhi hasil data yang reprodusibel dan realiabel maka sampel, pereaksi dan standar harus stabil pada waktu tertentu. Penentuan kestabilan serapan dilakukan untuk mengetahui waktu yang optimum dimana analisis pada selang waktu tersebut masih diperoleh nilai absorbansi yang cenderung stabil dan tidak dapat perbedaan yang signifikan pada nilai ansorbansi. Berdasarkan percobaan ini diperoleh serapan warna kompleks hasil reaksi antara natrium fluorida dengan pereaksi SPANDS-Asam zirkonil yang cukup stabil adalah menit ke-10 hingga menit ke-15 setelah penambahan pereaksi. Reaksi antara natrium fluorida dengan pereaksi SPANDS-Asam zirkonil dipengaruhi oleh keasaman dari reaksi campuran tersebut dan dapat dipengaruhi juga oleh waktu reaksi sehingga dalam pengukurannya harus sangat diperhatikan waktu analisis. 


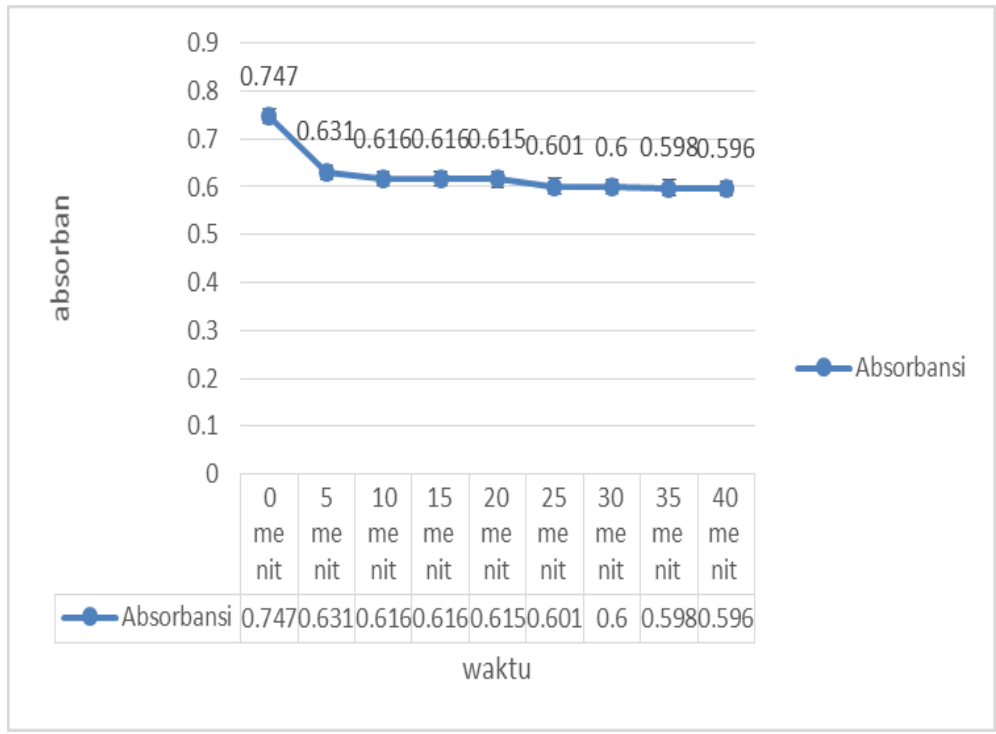

Gambar 2. Kurva kestabilan warna senyawa kompleks antara pereaksi SPADNS-asam zirkonil dengan larutan natrium fluoride

\section{Optimasi Pelarut}

Penetapan kadar diawali dengan dilakukan perbandingan metode preparasi sampel melalui perbandingan terhadap 3 pelarut yang berbeda.

Tabel I. Optimasi Pelarut

\begin{tabular}{cccc}
\hline Kode Sampel & $\begin{array}{c}\text { Air } \\
(\mathrm{mL} / \mathrm{L})\end{array}$ & $\begin{array}{c}\mathrm{HCl} \\
(\mathrm{mL} / \mathrm{L})\end{array}$ & $\begin{array}{c}\mathrm{HNO}_{3} \\
(\mathrm{~mL} / \mathrm{L})\end{array}$ \\
\hline $\mathrm{A}$ & 0,290 & 0,226 & 0,301 \\
$\mathrm{~B}$ & 0,275 & 0,229 & 0,298 \\
$\mathrm{C}$ & 0,247 & 0,227 & 0,294 \\
\hline
\end{tabular}

Data perbandingan pelarut pada Tabel I menunjukan bahwa ketiga pelarut yang di bandingkan, pelarut $\mathrm{HNO}_{3}$ pekat yang memberikan nilai absorbansi yang paling tinggi. $\mathrm{HNO}_{3}$ memberikan hasil ekstraksi yang optimum untuk semua parameter anorganik yang terukur dari pasta gigi di tetapkan $\mathrm{HNO}_{3}$ pekat sebagai pelarut untuk preparasi sampel.

\section{Verifikasi Metode Analisis Fluorida secara Spektrofotometri Sinar Tampak}

Verifikasi metode analisis perlu dilakukan untuk membuktikan bahwa metode yang digunakan memenuhi persyaratan sehingga dapat dinyatakan bahwa data yang diperoleh dari hasil penelitian merupakan hasil yang baik.

\section{Pembuatan Kurva Standar}

Pada penelitian ini, pembuatan kurva kalibrasi natrium fluorida yang dilakukan dengan membuat enam larutan seri standar natrium fluorida dengan berbagai konsentrasi yaitu 1 ; 1,$5 ; 2 ; 2,5 ; 3$ dan $3,5 \mu \mathrm{g} / \mathrm{ml}$. Persamaan kurva kalibrasi merupakan hubungan antara sumbu $\mathrm{x}$ dan sumbu $\mathrm{y}$, dimana deretan konsentrasi yang dibuat dinyatakan sebagai sumbu $\mathrm{x}$ sedangkan deretan absorbansi yang diperoleh dari hasil pengukuran dinyatakan sebagai sumbu y. Persamaan regresi linier dari kurva kalibrasi yang diperoleh adalah $\mathrm{y}=-0,1012 \mathrm{x}+$ 0,9559 dengan koefesien korelasi $r=0,9985$ (Gambar 3). Hasil ini cukup baik karena masuk 
dalam persyaratan linieritas menurut Harmita yaitu nilainya mendekati 1 dan nilai $r$ yang negatif menunjukkan respon analit yang berbanding terbalik.

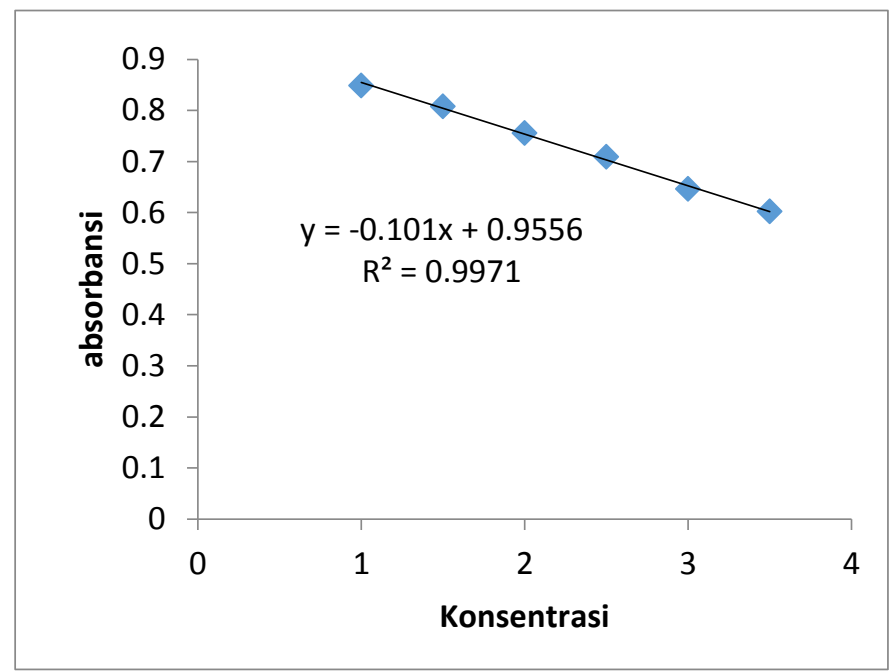

Gambar 3. Kurva Kalibrasi Larutan natrium fluorida dengan pereaksi SPADNS-Asam Zirkonil

\title{
Penentuan batas deteksi (LOD) dan batas kuantitasi (LOQ)
}

Batas deteksi (limit of detection) adalah jumlah konsentrasi analit terkecil dalam sampel yang masih dapat dideteksi dan dapat memberikan respon yang signifikan dibandingkan dengan blanko. Batas deteksi merupakan parameter uji batas yang spesifik. Batas kuantitasi (limit of quantitation) adalah jumlah konsentrasi analit terendah dalam sampel yang masih daapat memenuhi kriteria akurasi dan presisi. Batas deteksi dan Batas kuantitasi dapat dihitung dengan menggunakan persamaan regresi linier dari kurva kalibrasi, yang diperoleh dari hasil perhitungan menggunakan persamaan regresi linier batas deteksi natrium fluorida sebesar $0,1516 \mu \mathrm{g} / \mathrm{ml}$ dan batas kuantitasi natrium fluorida sebesar 0,5054 $\mu \mathrm{g} / \mathrm{ml}$.

\begin{abstract}
Akurasi
Uji akurasi ini menggunakan 3 konsentrasi larutan standar NaF yaitu $1 ; 2,5$ dan 3,5 $\mu \mathrm{g} / \mathrm{ml}$ yang ditambahkan sampel dengan jumlah tertentu, kemudian diukur absorbansinya dan dilakukan pengukuran terhadap sejumlah sampel dengan jumlah tertentu. Dihitung selisih konsentrasi tersebut dan dibandingkan dengan konsentrasi yang sebenarnya.

Uji prolehan kembali ini menggunakan metode adisi dengan pembagian tiga kelompok larutan uji yang tiap kelompoknya diberi larutan natrium fluorida dan ditambahkan dengan sampel hasil tersebut diperoleh dari konsentrasi $1 ; 2,5$ dan $3,5 \mu \mathrm{g} / \mathrm{ml}$ yang memberikan hasil perolehan kembali pada rentang 96,9733\%-118,99\%. Terjadinya perbedaan dari ketiga kelompok konsentrasi terjadi penyimpangan terhadap hasil pengukuran yang seharusnya. Penentuan akurasi suatu metode biasanya terdapat kesalahankesalahan yang menyebabkan nilai akurasi yang diperoleh menjadi lebih besar atau tidak tepat $100 \%$, kesalahan ini disebabkan karena adanya kesalahan personal seperti pemipetan, penimbangan dan kesalahan sistematis seperti peralatan.
\end{abstract}




\section{Presisi}

Presisi dari suatu metode analisis adalah derajat kesesuaian di antara masing-masing hasil uji, jika prosedur analisis diterapkan berulang kali pada sejumlah cuplikan yang diambil dari suatu sampel homogen. Presisi dinyatakan sebagai deviasi standar atau deviasi standar relatif $(R S D)$, (Satiadarma, 2004). Hasil pengukuran dengan melakukan secara tiga hari berturut-turut dengan konsentrasi $1 \mu \mathrm{g} / \mathrm{ml}$.

Berdasarkan data diperoleh nilai \%RSD sebesar $0,3 \%, 0,4 \%$, dan $0,5 \%$. Hasil ini menunjukkan bahwa metode uji yang digunakan pada penentuan kadar fluorida dengan spektrofotometri sinar tampak memiliki ketelitian yang baik, syarat nilai \%RSD yang diterima karena memberikan nilai $\leq 2 \%$. Nilai presisi dapat memberikan informasi bahwa metode ini dapat digunakan sebagai metode tetap pada laboratorium. Adanya variasi pada hasil presisi untuk tiga sampel tersebut disebabkan kesalahan acak. Kesalahan ini disebabkan karena adanya faktor yang tidak dapat dikendalikan. Kesalahan acak merupakan kesalahan dalam pengukuran karena gangguan dan perbedaan kondisi setiap pengukuran hingga menghasilkan angka yang berbeda.

\section{Penetapan Kadar Fluorida dalam Sampel Pasta Gigi}

Sampel pasta gigi yang telah dipreparasi terlebih dahulu dapat langsung dihitung kadar fluorida dengan menambahkan pereaksi SPANDS-Asam zirkonil. Dalam penetapan kadar fluorida sampel dipipet sebanyak $5 \mathrm{~mL}$ kemudian ditambahkan pereaksi SPANDSAsam zirkonil sebanyak $1 \mathrm{~mL}$. Penambahan pereaksi SPANDS-Asam zirkonil akan menghasilkan pembentukan kompleks baru yang berwarna merah sehingga dapat diukur kadarnya dengan menggunakan alat spektrofotometri sinar tampak.

Tabel II. Penetapan kadar fluorida pada sampel pasta gigi

\begin{tabular}{lcc}
\hline \multicolumn{1}{c}{ Sampel } & Absorbansi & $\begin{array}{c}\text { Konsentrasi } \\
(\mu \mathrm{g} / \mathrm{ml})\end{array}$ \\
\hline A1 (anak) & 0,233 & 725,346 \\
A2 & 0,283 & 665,940 \\
A3 & 0,226 & 722,376 \\
\hline B1 (online) & 0,219 & 729,306 \\
B2 & 0,280 & 669,10 \\
B3 & 0,249 & 699,603 \\
\hline C1 (hotel) & 0,392 & 558,019 \\
C2 & 0,239 & 709,504 \\
C3 & 0,423 & 527,326 \\
\hline
\end{tabular}

Berdasarkan hasil perhitungan kadar fluorida dalam sampel pasta gigi menunjukkan bahwa kadar fluorida diatas masih dalam rentang persyaratan yang dicantumkan oleh badan pengawasan obat dan makanan republik Indonesia nomor HK.03.1.23.08.11.07517 tahun 2011 tentang persyaratan kosmetik yang menetapkan bahwa kandungan fluorida pada pasta gigi untuk anak-anak adalah 500-1000 $\mu \mathrm{g} / \mathrm{ml}$ dan untuk dewasa $1000-1500 \mu \mathrm{g} / \mathrm{ml}$.

\section{KESIMPULAN}

Kondisi analisis optimum pada pengukuran fluorida diperoleh pada panjang gelombang $585 \mathrm{~nm}$ dengan waktu pengukuran dari menit ke-10 sampai menit ke-15 setelah penambahan pereaksi SPADNS-Asam zirkonil. Dalam preparasi sampel dilakukan terlebih dahulu, pelarut yang di gunakan HNO3 karena memberikan nilai hasil absorbansi yang paling besar. Hasil validasi dari analisis fluorida menunjukkan bahwa kriteria kurva 
kalibrasi, liniearitas, uji presisi, uji perolehan kembali, dimana hasil linieritas yang didapat $\mathrm{r}$ $=0,9985$, uji akurasi yang diperoleh dari $96,9733 \%,-118,9904 \%$, dan uji presisi di peroleh nilai RSD di bawah $2 \%$. Hasil analisis fluorida dengan 3 varian sampel pasta gigi menunjukkan hasil kadar antara 526,581 $\mu \mathrm{g} / \mathrm{ml}$ sampai $728,162 \mu \mathrm{g} / \mathrm{ml}$, dimana pasta gigi anak memiliki kadar yang cukup tinggi tetapi hasil tersebut masih dalam rentang yang dicantumkan oleh badan pengawasan obat dan makanan Republik Indonesia Nomor HK.03.1.23.08.11.07517 tahun 2011 tentang persyaratan kosmetik yang menetapkan bahwa kandungan fluorida pada pasta gigi untuk anak-anak adalah $500-1000 \mu \mathrm{g} / \mathrm{ml}$ dan untuk dewasa $1000-1500 \mu \mathrm{g} / \mathrm{ml}$.

\section{DAFTAR PUSTAKA}

Adwan, G., Salameh, Y., Adwan, K., Barakat, A.2012. Assessment of Antifungal Activity of Herbal and Conventional Toothpastes Against Clinical Isolates of Candida Albicans, Asian Pac J of Tropl Biomed., 2(5) : 375-379.

Angela, A. 2005. 'Pencegahan Primer Pada Anak Yang Beresiko Karies Tinggi. Majalah Kedokteran Gigi', Dental Journal, Vol. 38 (3): 130-134.

Barbier, O., Mendoza, L. A., Del Razo, L. M. 2010. 'Molecular Mechanisme of Fluoride Toxicity', Chemico Biological Interactions 188. 319-333.

Cosmetic Dentistry Guide. 2014.2 Toothpaste (http://www.cosmeticdentistryguide.co.uk/articles/toothpaste.html). Diunduh pada 22 Desember 2016.

Departemen Kesehatan Republik Indonesia. 1995. Farmakope Indonesia, Edisi IV. Direktorat Jendral Pengawasan Obat dan Makanan. Jakarta.

Donley, K. J. 2003 Fluoride Varnishes. Journal of Californian Dental Association.

Gartika M., Sasmita I.S., Muharam R. 2006. Teknik mikroabrasi sebagai salah satu alternatif perawatan dental fluorosis. Jurnal Kedokteran Gigi. Vol 2 h:65-72.

Gandjar, I. G. dan Rohman, A. 2007. Kimia Farmasi Analisis. Cetakan II. Yogyakarta: Pustaka Pelajar, p. 220-265;456-480.

Greenberg, A. E. 2005. Standard Methods for Examination of Water \& Wastewater, 21th edition. American Public Health Association 800 I Street NW. Washington, DC 20001-3710: (4)85-86.

Haris, N.O dan Garcia, F. 2004. Primary Preventive Dentistry, 6th ed, Upper Saddle River, New Jersey, p. 119-129, 841.

Haveles, E.B. 2011. Applied Pharmacology For the Dental Hygienist, 6th ed, Mosby Elsivier, Riverport lane, p. 179-183, 367.

J. fawel, k. baley, j. Chilton, e. dahi, 1. fewtrell and y. Magara. 2006. Fluoride in dringking water. Publisher on behalf of the world health organization by IWA publishing, Alliance house, 12 caxton street, London SW1H0Qs, UK.

Kepala Badan Pengawasan Obat dan Makanan. 2010. Persayaratan Teknis Kosmetika BAB II Persyaratan Teknis. Badan Pengawasan Obat dan Makanan Republik Indonesia.

Kidd, E. A. M; dan S. J. Bechal. 1991. Dasar-Dasar Karies. Alih Bahasa Narlan Sumawinata dan Safrida Faruk. Jakarta : EGC. 30-31.

Lubis. S.L.A. 2001. Fluor dalam Pencegahan Karies Gigi. USU e-Repository.

Meier, K.H. 2007. Fluoride in Posioningang Drug Overdose, Fifth Edition, Olson, KR. (Ed) McGraw-HillCompanies, Inc. New York.

Philip, D.M., Michael, V.M. 2009. Oral Microbiology, 5th ed, Churchill Livingstone Elsever, Inggris, p.30-33, 213.

Retno I.S. Tranggono. 1992. Kiat Apik Menjadi Sehat dan Cantik. Jakarta : Gramedia Pustaka Utama.

Rosen, S. 1991. Dental Caries. Dalam Willet. N. P.; R. R. White.; and S. Rosen. Essential Dental Microbiology. London : Prentice-Hall International Inc. 345-351.

RSCP Publishing. 2013. The Merck Index of Encyclopedia of Chemicals, Drug and Biological. Fifteenth edition. The Royal Society of Chemistry, pp 1559 
Jurnal Medical Sains 2(2), 89-97

Penetapan Kadar Fluorida Pada Sampel Pasta Gigi .... (Ivan Andriansyah)

Swartz, M. E. and Krull, I. S. 2012. Handbook of Analytical Validation. Taylor \& Francis Group, LLC, p. 61-75. 